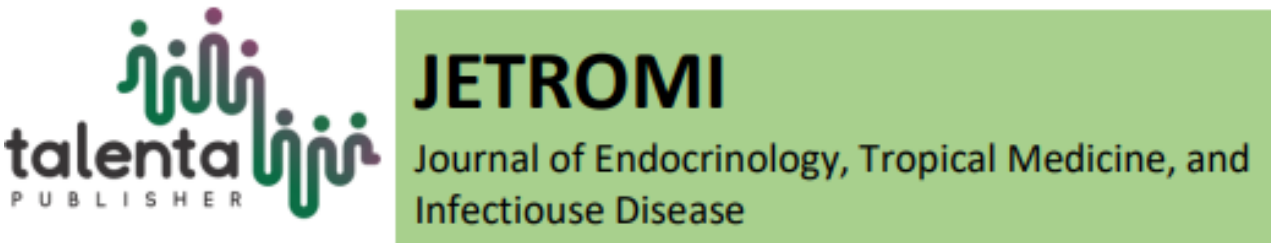

\title{
The Differences of TNF- $\alpha$ Levels and BMI in Diabetic Patients With Pulmonary Tuberculosis After Intensive Phase of Tuberculosis Treatment
}

\author{
Wika Lydia', Muhammad Aron Pase ${ }^{2}$, Melati Silvani Lubis ${ }^{3}$, Dian Anindita \\ Lubis $^{4}$ \\ ${ }^{1}$ Department of Internal Medicine, Faculty of Medicine, Universitas Sumatera Utara \\ ${ }^{2,3,4}$ Division of Endocrinology Metabolic and Diabetes, Department of Internal Medicine, Faculty of \\ Medicine, Universitas Sumatera Utara
}

\begin{abstract}
Diabetes Melitus (DM) can cause complications, such as pulmonary tuberculosis (TB). Metabolic disorders are thought to be related to Tumor Necrosis Factor- $\alpha$ (TNF- $\alpha$ ) metabolism, adipocytokines secreted by macrophages, which inhibit insulin transduction, has anti-mycobacterial activity, however, also negatively affect pathological TB process. This study aims to determine differences in TNF- $\alpha$ levels and Body Mass Index (BMI) in DM with pulmonary TB after intensive phase of antituberculosis treatment. This prospective comparative analytical study with one-group pretest-posttest design, conducted during August 2019-September 2019 in outpatient of Type 2 DM with pulmonary TB at USU Hospital, Madani Medan Hospital, Teladan Health Center and Laboratory of Haji Adam Malik Medan after approval from the Health Research Ethics Commission. Data were analyzed after normality test, then mean difference and correlation test by using the SPPS program where $p<0.05$ was considered significant. This study showed an increase BMI, and decrease of fasting blood glucose, 2-hour post-prandial blood glucose, HbA1C and TNF $\alpha$ levels before and after intensive phase of antituberculosis treatment $(\mathrm{p}=0.001 ; \mathrm{p}$ $=0.001 ; p=0.001 ; p=0.001)$. There was a significant increase of BMI and decrease of $\mathrm{TNF} \alpha$ level after intensive phase of antituberculosis treatment.
\end{abstract}

Keyword: T2DM, Lung Tuberculosis, Antituberculosis treatment, Tumor Necrosis Factor $\alpha$

\begin{abstract}
Abstrak. Diabetes Melitus (DM) dapat menimbulkan berbagai macam komplikasi, salah satunya Tuberkulosis (TB) paru. Gangguan metabolik diduga berkaitan dengan metabolisme Tumor Necrosis Factor- $\alpha$ (TNF- $\alpha)$, adipositokin yang disekresikan makrofag yang dapat menghambat transduksi insulin, diketahui memiliki aktivitas anti-mikrobakteri, dan berdampak negatif dalam proses patologis TB. Penelitian ini bertujuan mengetahui perbedaan kadar TNF- $\alpha$ dan Indeks Massa Tubuh (IMT) pasien DM dengan TB paru setelah fase intensif pengobatan TB. Penelitian prospektif one group pretest-posttest ini bersifat analitik komparatif, dilaksanakan dari bulan Agustus 2019-September 2019 pada penderita DM Tipe 2 dengan TB paru di poliklinik rawat jalan RS USU, RS Madani Medan, Puskesmas Teladan serta Laboratorium RSUP Haji Adam Malik Medan setelah mendapat persetujuan Komisi Etik Penelitian Bidang Kesehatan. Data dianalisis setelah uji distribusi, kemudian dilakukan uji beda mean dan uji korelasi menggunakan program SPPS di mana $p<0,05$ dianggap signifikan. Penelitian ini menunjukkan adanya peningkatan nilai IMT, serta penurunan kadar GDP, GD2PP, HbA1C dan TNFa yang signifikan antara sebelum dan setelah fase intensif pengobatan TB $(p=0,001 ; p=0,001 ; p$
\end{abstract}

${ }^{*}$ Corresponding author at: Department of Internal Medicine, Faculty of Medicine, Universitas Sumatera Utara

E-mail address: wikadr29@gmail.com 
$=0,001 ; p=0,001)$. Terjadi peningkatan IMT dan penurunan kadar TNF $\alpha$ yang signifikan setelah 2 bulan pengobatan dengan OAT.

Kata Kunci: DM Tipe 2, Tuberkulosis Paru, Obat Antituberkulosis, Tumor Necrosis Factor- $\alpha$

Received 12 April 2020 | Revised 24 April 2020 | Accepted 11 May 2020

\section{Introduction}

There is an increase prevalence of Diabetes mellitus (DM) worldwide. The number of DM patients in the world was around 415 million, and estimated to be increased about 642 million in 2040 [1]. DM can cause a variety of complications, one of which is pulmonary tuberculosis (TB). This was increase of TB cases in patients with DM, especially in the area of epidemic of DM and TB such as China, India and Indonesia. The prevalence of the pulmonary TB in DM increased 20 times higher, compared to the prevalence of pulmonary TB in non-DM patients. A study reported that the prevalence of TB patients in Indonesia was $12.8 \%-42 \%$ [2].

World Health Organization (WHO) states that in 2014, there were 9.6 million pulmonary tuberculosis patients all around the world and Indonesia was the second highest prevalence to the largest pulmonary tuberculosis case after India [3]. The progress of pulmonary tuberculosis disease in DM patients tends to be severe and chronic [2][4]. One of the risk factors of DM Type 2 Diabetes Mellitus (T2DM) is excess weight, but diabetic patients tend to undergo weight loss along with disease progress. Pulmonary tuberculosis is a chronic disease that also contributes to the symptoms of weight loss [5].

Metabolic disorders such as obesity and insulin resistance are suspected to have related to the metabolism of TNF- $\alpha$. Several studies had shown the relationship between TNF- $\alpha$, obesity and T2DM [6]. According to previous studies, TNF- $\alpha$ was involved in the pathogensis of insulin resistance which affects the incidence of Type 2 Diabetes Melitus and the progression of this disease. However, the role of TNF- $\alpha$ in the progression of DM remains unclear [7].

TNF- $\alpha$ is an adipocytokine that is involved in systemic inflammation and stimulates the acute phase of immune reaction. TNF- $\alpha$ is mainly secreted by macrophages, and also by various other cells including adipocytes. TNF- $\alpha$ inhibits the transduction of insulin, and has an effect on glucose metabolism, so TNF- $\alpha$ can affect the onset and progression of [7]. In addition, TNF- $\alpha$ has antimicrobial activity by stimulating the formation of granulomas in tuberculosis patients [8]. The recruitment of inflammatory cells in the lung infection process by TB also increased the production of TNF- $\alpha$ cytokines, which helped determine the process of forming granulomas in patients. Until now, there is still no previous studies on the changes of the TNF- $\alpha$ levels in T2DM patients with pulmonary tuberculosis after anti-tuberculosis treatment. Therefore, the author wants to know the differences in the TNF- $\alpha$ levels and body mass index (BMI) in T2DM patients with pulmonary tuberculosis after intensive phase of anti-tuberculosis treatment. 


\section{Methods}

This is a comparative analytical research with a prospective approach. This one group Pretestposttest study, aims to determine the difference of TNF- $\alpha$ levels and body mass index in T2DM patients with pulmonary tuberculosis after intensive phase of anti-tuberculosis treatment. This study was held in August 2019-September 2019 and patients with DM type 2 and pulmonary TB were the outpatient clinic of USU Hospital, Madani Medan Hospital, Teladan Health Center and specimen were examined in the Laboratory of RSUP Haji Adam Malik Medan after receiving approval from the Health and Research Ethics Commission. Data was analyzed after the distribution test, and continued by conducting the mean test and correlation test using SPPS program, which $p<0.05$ is considered significant.

\section{Results}

Table 1 below showed the characteristics of respondents in this study. There were 25 respondents, $19(76 \%)$ were male, and $6(24 \%)$ were female, with a mean value of age of 52.6 years old.

\section{Tabel 1. Characteristics of Respondents}

\begin{tabular}{|c|c|}
\hline Variables & $\begin{array}{l}\mathbf{n}=\mathbf{2 5} \\
\mathrm{X} \pm \mathrm{SD}\end{array}$ \\
\hline \multicolumn{2}{|l|}{ Gender } \\
\hline Male, n (\%) & $19(76)$ \\
\hline Female, n (\%) & $6(24)$ \\
\hline Age (year) & $52.6 \pm 6.39$ \\
\hline Hemoglobin (g/dL) & $11.27 \pm 0.96$ \\
\hline Leukocyte $\left(/ 10^{3} \mathrm{~mm}^{3}\right)$ & $8.87 \pm 2.95$ \\
\hline Platelets $\left(/ 10^{3} \mathrm{~mm}^{3}\right)$ & $341.72 \pm 112.21$ \\
\hline BMI $\left(\mathrm{kg} / \mathrm{m}^{2}\right)$ & $21.35 \pm 1.33$ \\
\hline $\mathrm{FBG}(\mathrm{g} / \mathrm{dL})$ & $193.92 \pm 50.78$ \\
\hline 2-hr PP Blood Glucose (g/dL) & $269.36 \pm 80.11$ \\
\hline $\operatorname{HbA} 1 \mathrm{C}(\mathrm{g} \%)$ & $9.40 \pm 0.96$ \\
\hline $\mathrm{TNF} \alpha(\mathrm{pg} / \mathrm{mL})$ & $503.87 \pm 77.02$ \\
\hline
\end{tabular}

BMI : body mass index; FBG : fasting blood glucose; 2 -hr PP blood glucose : 2-hour postprandial blood glucose; HbA1C : glycylated hemoglobin; TNF $\alpha$ : tumor necrosis factor alpha

This study showed an increase of mean value of BMI value, as well as a significant decrease of mean fasting blood glucose, 2-hour post-prandial blood glucose, HbA1C and TNF $\alpha$ levels before and after intensive phase of antituberculosis treatment $(p=0.001 ; p=0.001 ; p=0,001 ; p$ $=0.001)($ Table 2$)$. 
Table 2. Comparison of Anthropometry and Laboratory Parameters Before and After

Intensive Phase of Antituberculosis Treatment

\begin{tabular}{lccc}
\hline Variable & $\begin{array}{c}\text { Before } \\
\text { Antituberculosis } \\
\text { Treatment }\end{array}$ & $\begin{array}{c}\text { After } \\
\text { Antituberculosis } \\
\text { Treatment }\end{array}$ & p \\
\hline BMI $\left(\mathrm{kg} / \mathrm{m}^{2}\right)$ & $21.35 \pm 1.33$ & $22.16 \pm 1.16$ & 0.001 \\
FBG $(\mathrm{g} / \mathrm{dL})$ & $193.92 \pm 50.78$ & $114.2 \pm 18.35$ & 0.001 \\
2-hr PP Blood Glucose $(\mathrm{g} / \mathrm{dL})$ & $269.36 \pm 80.11$ & $181.64 \pm 23.54$ & 0.001 \\
$\mathrm{HbA1C}(\mathrm{g} \%)$ & $9.40 \pm 0.96$ & $8.66 \pm 0.91$ & 0.001 \\
$\mathrm{TNF} \alpha(\mathrm{pg} / \mathrm{mL})$ & $503.87 \pm 77.02$ & $344.70 \pm 57.69$ & 0.001 \\
\hline
\end{tabular}

BMI : body mass index; FBG : fasting blood glucose; 2-hr PP blood glucose : 2-hour post-prandial blood glucose; $\mathrm{HbA1C}$ : glycylated hemoglobin; TNF $\alpha$ : tumor necrosis factor alpha

Table 3. Correlation Test of Variables of Risk Factors and TNFa Before and After Intensive Phase of Antituberculosis Treatment

\begin{tabular}{lcc}
\hline Variabel & r & p \\
\hline $\mathrm{BMI}\left(\mathrm{kg} / \mathrm{m}^{2}\right)$ & 0.880 & 0.001 \\
FBG $(\mathrm{g} / \mathrm{dL})$ & -0.292 & 0.157 \\
2-hr PP Blood Glucose $(\mathrm{g} / \mathrm{dL})$ & -0.032 & 0.530 \\
$\mathrm{HbA1C}(\mathrm{g} \%)$ & 0.827 & 0.001 \\
$\mathrm{TNF} \alpha(\mathrm{pg} / \mathrm{mL})$ & 0.791 & 0.001 \\
\hline
\end{tabular}

BMI : body mass index; FBG : fasting blood glucose; 2-hr PP blood glucose : 2-hour postprandial blood glucose; HbA1C : glycylated hemoglobin; TNF $\alpha$ : tumor necrosis factor alpha

Correlation test showed that the BMI, HbA1C and TNF $\alpha$ levels after intensive phase of antituberculosis treatment have a significant relationship and are positively correlated $(\mathrm{r}=$ $0.880 ; \mathrm{r}=0.827 ; \mathrm{r}=0.791$ ). This means that the higher the BMI, HbA1C and TNF $\alpha$ level before intensive phase of antituberculosis treatment, the BMI, $\mathrm{HbA1C}$ and $\mathrm{TNF} \alpha$ levels will be higher also after intensive phase of antituberculosis treatment. The correlation test results also indicate that in this study, although there was a negative correlation of fasting blood glucose and 2-hour post prandial blood glucose levels, they had no significant relationship $(r=-0.292 ; r=0-, 032)$ [Table 3].

\section{Discussion}

In this study, there were differences in the average value of body mass index in TB patients who had undergone OAT treatment for intensive phase $(\mathrm{p}=0.001)$. Some previous studies have tried to determine the linkage between the differences in weight in conjunction with the treatment of antituberculosis. Similar to the results of this study, Chung-Delgado, et.al [9] stated that there was a significant weight increase in TB patients undergoing OAT treatment $(\mathrm{p}<0.001)$. Phan, et.al. [10] in his study, expressed that, most his respondents (52.6\%) experienced an increase in body weight in the intensive phase after the antituberculosis treatment, but only $38.4 \%$ of the groups that experienced the weight gain, were finally gaining weight in the overall treatment regimen $(\mathrm{p}<0.001)$. Bernabe-Ortiz, et.al. in [11] expressed the similar results, where there was 
a significant weight gain when conducting research with a sample of TB patients undergoing a given treatment regimen and having a good outcome $(\mathrm{p}<0.001)$ although some of them were experiencing weight loss especially in groups with poor outcomes $(\mathrm{p}<0.003)$. Hoa, Lauritsen and Rieder [12] specifically found significant weight increase especially occurring within the intensive phase of post antituberculosis treatment.

The mechanism of decline and increase in weight in TB cases remains unclear. Although with increased intake of calories and macronutrients, TB infection can still lead to a decrease in fat and non-fat mass [13]. The difference in the results can be obscured by the factors of the disease itself such as the severity of the disease, smear results, as well as the initial weight when the treatment started. Severe malnourishment in the early course of treatment showed a significant increase in body weight when there was adequate nutrients given. The decrease of the bacillary load occurs mainly in the intensive phase, where it allows the body to re-fill the fat deposits.

Mycobacterium tuberculosis (MTB) has a reciprocal relationship with blood sugar control. According to Segura-Cerda, et.al.[14], high levels of blood sugar cause a defect in immunity to MTB infection. Almeida-Junior, et.al. [15] states that there was a correlation between lung damage caused by MTB in patients with T2DM. The hyperglycemic state has direct effect on the role of macrophages which was the first line in the mechanism against MTB infection. Niazi and Kalra [16] showed a decrease in the levels of Th1, cytokines, TNF $\alpha$, IL-1 and IL-6 levels in diabetic patients, compared to non-diabetic patient. Such decline leads to an impaired control and inhibition of MTB, mainly due to a decrease in the number of the T cell lymphocytes, and impaired macrophage function along with the production of reactive oxidative stress and the impaired function of phagocytosis and chemotaxis. Montoya-Rosales, et.al. [17] found a negative correlation between glucose concentration and MTB phagocytosis process. Studies showed that there were a decline in expression of CD86, CD80 and HLA-DR (molecules that had a role in the activation of antigen presentations and Th cell response), which may reduce the levels of IL-6 cytokines, IL-1 $\beta$, IL-10 and IL-12.

There were several mechanisms which MTB can lead to hyperglycemic state, such as, stress due to infectious diseases may increase cortisol hormone production, which in turn can increase the blood sugar levels. In addition, also the release of various cytokine compounds, chemokines and tuberculosis proteins may cause pancreatic dysfunction or known as "concomitant pancreatitis". This dysfunction led to an increase of amylin deposition in the pancreas due to the increase of the function of beta cells due to transient hyperglycemic state. This may lead to the MTB germ invasion of the pancreas [18].

In this study, control of blood sugar was determined by the examination of fasting blood glucose levels, 2-hour post-prandial blood glucose and HbA1C levels, in which in this study, were found decrease significantly $(p=0.001 ; p=0.001 ; p=0.001)$. Research by Gurukartick, 
et.al. [19] stated that there was an increase in the number of TB patients with DM which has a controlled blood sugar level, as well as a decrease in the number of TB patients with DM that did not have uncontrolled sugar levels. Although there were some numbers of samples in his research lost, but the test of blood sugar levels from before, after intensive phase and after the advanced phase, showed that there was an increasing number of patients who have a controlled sugar level, as well as a decrease in the number of patients who have uncontrolled sugar levels [19]. Krishnappa, et.al. [18] found $65.4 \%$ of the samples were converted to euglycemic status in his research on TB patients with T2DM. Through an adequate antituberculosis treatment, especially in the intensive phase, by suppressing the amount of MTB in turn can contribute to the control of blood sugar.

TNF- $\alpha$ is an adipocytokine that is involved in acute-phase of systemic inflammatory reactions, which is mainly secreted by macrophages, but also by various other cells including adipocytes. In relation to T2DM, TNF- $\alpha$ may inhibit insulin transduction, which affects glucose metabolism. TNF- $\alpha$ is known to play a role in the onset and development of diabetes mellitus type 2 [7]. In relation to the MTB infection, TNF- $\alpha$ has two opposite roles in MTB infection, as the resulting cytokines have the simultaneous potential to assist and inhibit the immune response to MTB [8]. TNF- $\alpha$ has an antimicrobial activity by stimulating the formation of granulomas in tuberculosis patients [8]. TNF- $\alpha$ can maintain the state of the dormancy of MTB infections in humans, because TNF- $\alpha$ inhibition may decrease the ability to restrict the growth of MTB. TNF- $\alpha$ is also shown to directly exert anti-mycobacteria activity in human mononuclear phagocytes.

In this study, the author found a decrease in $\mathrm{TNF} \alpha$ levels after intensive phase of antituberculosis treatment $(\mathrm{p}=0.001)$. It is in accordance with the research by Kim, et.al. [20] stating that there was a decrease in TNF $\alpha(\mathrm{p}<0.05)$ after intensive phases of antituberculosis treatment. Research conducted by Mvungi, et.al. in [21] also showed a decrease in TNF $\alpha$ levels after intensive phase of antituberculosis treatment. The authors also stated that the decrease in the TNF $\alpha$ levels occurred up to $41.5 \%$ ( $\mathrm{p}<0.0001$ ). In addition, there was a decline in other cytokine levels such as IFN- $\gamma$, IL-6, IL-10, and IL-4 ( $<<0.0001$ ). They have also stated that the increase and decrease in cytokines can be a predictor in the assessment of the immunological response after the antituberculosis therapy, so that in turn can help in providing an overview of the progression of the disease and reducing other additional costs that may be required in treating these cases which were unresponsive or resistant.

The study showed that there was a relationship between the TNF $\alpha$ levels before and after intensive phase of antituberculosis treatment in T2DM patients. However, there were some limitations in this study. In this study, researchers sought to assess the body mass index, however, researchers have not yet listed and conducted assessments of other factors that could 
influence the body mass index, such as information on body composition, food intake, and else. This can be a primarily cofounding factors for cases in which TB patient did not have sufficient nutritional intake, so the BMI value changes might be less accurate. In addition, there were other infections factors, such as patients with HIV that generally had low BMI. Futhermore, there were also various socioeconomic factors that were important and might affect the BMI, in which, TB patients were usually associated with low socioeconomics. The improvement of BMI in TB and DM patients was also associated with the duration of treatment, meanwhile in this study, only includes follow up to intensive phase of treatment. In this study, there was conducted assessment of blood sugar levels. There were several factors that can determine blood sugar levels, such as physical activity, measurement of blood sugar levels often become inaccurate even though in this research in particular also assess the HbA1C level. This research has not done the stratification of the severity of TB infection or DM, so that the results obtained are still less practical in daily practice. The research also did not consider the treatment being taken and the pharmacodynamic interactions between the use of antituberculosis and oral hypoglycemic agent or insulin used in this study.

\section{Conclusion}

There was a statistically significant increase of BMI and decrease of TNF $\alpha$ level after intensive phase of antituberculosis treatment.

\section{REFERENCES}

[1] International Diabetes Federation. IDF Diabetes Atlas. $7^{\text {th }}$ edition. International Diabetes Federation. 2015.

[2] Sanusi H. Diabetes melitus dan tuberkulosis paru. Jurnal Medika Nusantara, vol. 25, no. 1. 2015.

[3] World Health Organization. Global Report on Diabetes. France: World Health Organization. 2016.

[4] Cahyadi A dan Venty. Tuberkulosis paru pada pasien diabetes mellitus. Majalah Kedokteran Indonesia, vol. 61, no. 4, pp. 173-178. 2011.

[5] Amin Z dan Bahar A. Tuberkulosis paru. Buku Ajar Ilmu Penyakit Dalam. Jilid II. Edisi ke-4. Jakarta: Pusat Penerbitan Departemen Ilmu Penyakit Dalam Fakultas Kedokteran Universitas Indonesia. pp.998-1000. 2006.

[6] Ehlers S, Kaufmann SH, Participants of the 99(th) Dahlem Conference. Infection, inflammation, and chronic diseases: consequences of a modern lifestyle. Trends Immunol, vol. 31, pp. 184-90. 2010.

[7] Swaroop JJ, Rajarajeswari D, Naidu JN. Association of TNF- $\alpha$ with insulin resistance in type 2 diabetes mellitus. Indian J Med Res, vol. 135, pp. 127-130. 2012.

[8] Mootoo, A. et al. 2009. TNF- $\alpha$ in Tuberculosis: A Cytokine with a Split Personality. Inflammation \& Allergy-Drug Targets, 8(1), pp.53-62. 
[9] Chung-Delgado K, Revilla-Montag A, Guillen-Bravo S, dan Bernabe-Ortiz A. Weight variation over time and its relevance among multidrug-resistant tuberculosis patients. Int J Infect Dis, vol. 23, pp. 20-4. 2011.

[10] Phan MN, Guy ES, Nickson RN, Kao CC. Predictors and patterns of weight gain during treatment for tuberculosis in the United States of America. International Journal of Infectious Diseases, vol. 53, pp. 1-5. 2016.

[11] Bernabe-Ortiz A, Carcamo CP, Sanchez JF, dan Rios J. Weight variation over time and its association with tuberculosis treatment outcome: a longitudinal analysis. PLoS One, 6:e18474. 2011.

[12] Hoa NB, Lauritsen JM, dan Rieder HL. Changes in body weight and tuberculosis treatment outcome in Viet Nam. Int J Tuberc Lung Dis, vol. 17, pp. 61-6. 2013.

[13] Frediani JK, Sanikidze E, Kipiani M, Tukvadze N, Hebbar G, Ramakrishnan U, et.al. Macronutrient intake and body composition changes during antituberculosis therapy in adults. Clinical Nutrition, pp. 1-8. 2015.

[14] Segura-Cerda CA, Lopez-Romero W, dan Flores-Valdez MA. Changes in Host Response to Mycobacterium tuberculosis Infection Associated With Type 2 Diabetes: Beyond Hyperglycemia. Frontiers in Cellular and Infection Microbiology, vol. 9, no. 342. 2019.

[15] Almeida-Junior, J. L., Gil-Santana, L., Oliveira, C. A., Castro, S., Cafezeiro, A. S., Daltro, C., et al. Glucose metabolism disorder is associated with pulmonary tuberculosis in individuals with respiratory symptoms from Brazil. PLoS ONE, 11:e0153590. 2016.

[16] Niazi AK dan Kalra S. Diabetes and tuberculosis: a review of the role of optimal glycemic control. Journal of Diabetes \& Metabolic Disorders, vol. 11, p. 28. 2012.

[17] Montoya-Rosales, A., Castro-Garcia, P., Torres-Juarez, F., Enciso-Moreno, J. A., and Rivas-Santiago, B. Glucose levels affect LL-37 expression in monocyte-derived macrophages altering the Mycobacterium tuberculosis intracellular growth control. Microb. Pathog, vol. 97, pp. 148-153. 2016.

[18] Krishnappa D, Sharma SK, Singh AD, Sinha S, Ammini AC, Soneja M. Impact of tuberculosis on glycaemic status: A neglected association. Indian J Med Res, vol. 149, pp. 384-388. 2019.

[19] Gurukartick J, Murali L, Shewade HD, Jacob AG, Samy MM, Dheenadayal D, et.al. Glycemic control monitoring in patients with tuberculosis and diabetes: a descriptive study from programmatic setting in Tamil Nadu, India [version 1; peer review: awaiting peer review], F1000Research, vol. 8, p. 1725. 2019.

[20] Kim CH, Yoo SS, Lee SY, Cha SI, Park JY, Lee J. Post-treatment change in Mycobacterium tuberculosis antigenstimulated tumor necrosis factor-alpha release in patients with active tuberculosis. J Thorac Dis 2015, vol. 7, no. 5, pp. 903-907. 2015.

[21] Mvungi HC, Mbelele PM, Buza1 JJ, Mpagama SG, Sauli E. Blood Cytokine Responses to Early Secreted Protein Antigen-6/Culture Filtrate Protein-10 Tuberculosis Antigens 2 Months After Antituberculosis Treatment among Patients with Drug-Susceptible 
Pulmonary Tuberculosis. International Journal of Mycobacteriology, vol. 8, pp. 53-59. 2019 